\title{
Hubungan Bimbingan Belajar Orang Tua dan Konsep Diri dengan Hasil Belajar Matematika
}

\author{
I K.J. Wirawan ${ }^{1 *}$, I M. Suarjana ${ }^{2}$, N.T. Renda3 \\ 1,2,3 Jurusan Pendidikan Guru Sekolah Dasar (PGSD), Universitas Pendidikan Ganesha, Singaraja, Indonesia.
}

\author{
A R T I C L E I N F O \\ Article history: \\ Received 19 February \\ 2018 \\ Received in revised form \\ 07 March 2018 \\ Accepted 19 April 2018 \\ Available online 21 May \\ 2018 \\ Kata Kunci: \\ bimbingan belajar orang \\ tua, konsep diri, hasil \\ belajar matematika \\ Keywords: \\ parents learning guidance, \\ self-concept, result of \\ learning mathematics
}

\begin{abstract}
A B S T R A K
Penelitian ini bertujuan untuk mengetahui: (1) hubungan anatara bimbingan belajar orang tua dengan hasil belajar matematika, (2) hubungan antara konsep diri dengan hasil belajar matematika, (3) hubungan anatara bimbingan belajar orang tua dana konsep diri dengan hasil belajar matematika siswa kelas III semester II di SD Gugus Xii Kecamatan Buleleng tahun pelajaran 2017/2018. Jenis penelitian ini merupakan penelitian korelasional. Populasi dari penelitian ini berjumlah 169 orang dengan jumlah sampel sebanyak 114 orang diambil dengan teknik proporsional random sampling. data bimbingan belajar orang tua dan konsep diri di kumpulkan melalui pengisian kuesioner. Sedangkan data hasil belajar matematika diperoleh melalui pencatatan dokumen (document analyze). Data dianalisis dengan teknik statistic deskriptif dan analisis regresi. Hasil analisis data menunjukkan: (1) hubungan antara bimbingan belajar orang tua dengan hasil belajar matematika sebesar $=0,367$ dan koefisien determinasinya sebesar $13,5 \%$, artinya terdapat hubungan yang signifikan antara bimbingan belajar orang tua dengan hasil belajar matematika. (2) hubungan antara konsep diri dengan hasil belajar matematika sebesar $=0,450$ dan koefisien
\end{abstract} determinasinya sebesar $20,3 \%$, artinya terdapat hubungan yang signifikan antara konsep diri dengan hasil belajar matematika. (3) hubungan antara bimbingan belajar orang tua dan konsep diri dengan hasil belajar matematika sebesar $=0,461$ dan koefisien determinasinya sebesar $21,3 \%$, artinya terdapat hubungan yang signifikan antara bimbingan belajar orang tua dan konsep diri dengan hasil belajar matematika siswa kelas III Semester II di SD Gugus XII Kecamatan Buleleng tahun pelajaran $2017 / 2018$

\section{A B S T R A C T}

This study aims to determine: (1) the relationship between parents learning guidance with the results of learning mathematics, (2) the relationship between self-concept with the results of learning mathematics, (3) relationship between parents learning guidance and self concept with the result of learning mathematics of third grade semester II at SD Gugus XII Buleleng District, in the academic year 2017/2018. The type of research is used a correlation research. The population of this study amount to 169 people with a total sample of 114 people took by the technique of Proportional Random Sampling. The data of parents course and self-concept is collected through filling the questionnaire, while result of data learning mathematics obtained by document recorder (document analyze). The data were analyzed by descriptive statistic technique and regression analysis. The results of data analysis show: (1) the relationship between parents learning guidance with mathematics learning outcome of $=0,367$ and the coefficient of determination of $13.5 \%$, meaning there is a significant relationship between parents course with the results of learning mathematics. (2) the relationship between self-concept with the result of learning mathematics of $=0,450$ and coefficient of determination equal to $=20,3 \%$, meaning there is a significant correlation between self concept and the result of learning mathematics. (3) the relationship between parents learning guidance and self concept with the result of learning mathematics equal to $=0,461$ and coefficient of determination equal to $=21,3 \%$, meaning there is significant correlation between parents course and self concept with the result of learning mathematics.

Copyright () Universitas Pendidikan Ganesha. All rights reserved.

E-mail addresses: julianawirawan560@gmail.com (I K.J. Wirawan) 


\section{Pendahuluan}

Pendidikan merupakan hal yang sangat penting di dalam memajukan suatu bangsa. Melalui pendidikan diharapkan dapat menghasilkan sumber daya manusia (SDM) yang berkualitas yang berguna bagi nusa dan bangsa Indonesia. Menurut Anwar (2015) dikatakan bahwa, pendidikan mampu mengembangkan potensi-potensi pembawaan, baik jasmani maupun rohani sesuai dengan nilai-nilai yang ada dalam masyarakat dan kebudayaan serta mampu menciptakan sumber daya manusia (SDM) yang berkualitas. UU No. 20 Tahun 2003, Bab II Pasal 3 menyatakan bahwa Pendidikan nasional berfungsi mengembangkan kemampuan dan membentuk watak serta peradaban bangsa yang yang bermartabat dalam rangka mencerdaskan kehidupan bangsa, bertujuan untuk berkembangnya potensi peserta didik agar menjadi manusia yang beriman dan bertqwa kepada Tuhan Yang Maha Esa, berakhlak mulia, sehat, berilmu, cakap, kreatif, mandiri, dan menjadi warga negara yang demokratis serta bertanggung jawab. Untuk mencapai tujuan pendidikan tersebut tentu harus melaui jenjang pendidikan, di sekolah, peserta didik tidak hanya diajarkan pada aspek pengetahuan saja melainkan juga pada aspek sikap serta keterampilan yang terdapat di setiap mata pelajaran yang diajarkan.

Menurut UU No. 20 Tahun 2003, Bab X, Pasal 37 ayat (1) salah satu mata pelajaran yang wajib dimuat dalam kurikulum pendidikan dasar dan menengah adalah mata pelajaran matematika. Matematika merupakan salah satu mata pelajaran dasar yang dibelajarkan di sekolah termasuk di sekolah dasar (SD). Menurut Mulyana (dalam Eva, 2013) mata pelajaran matematika perlu dan penting diberikan kepada peserta didik karena, selain dapat memperluas cakrawala berpikir peserta didik juga dapat mengembangkan kesadaran tentang nilai-nilai yang secara esensial terdapat didalamnya. Fungsi Aplikasi ilmu matematika di Sekolah Dasar lebih mengutamakan pada pembentukan sikap kreatif, kritis dan logis serta mampu menggunakannya dalam pemecahan masalah yang berhubungan dengan kehidupan seharihari.dan sebagai pendukung di dalam pengembangan ilmu pengetahuan dan teknologi (Sunilawati,2014). Adapun tujuan pembelajaran matematika di sekolah dasar adalah agar siswa mampu dan terampil dan juga dapat memberikan tekanan nalar dalam penerapannya sehari-hari (Susanto, 2013).

Untuk tercapainya tujuan pembelajaran matematika khususnya untuk meningkatkan hasil belajar matematika siswa, tentu tidak bisa hanya mengandalkan peran guru saja melainkan ada faktor lain yang berperan penting salah satunya adalah peran orang tua dan konsep diri siswa. Melalui bimbingan belajar orang tua yang diberikan kepada anak secara tidak langsung akan mempengaruhi konsep diri anak untuk meningkatkan hasil belajarnya demi tercapainya tujuan pembelajaran matematika. Muhibbin (2015:146155) menyatakan "faktor-faktor yang mempengaruhi kemampuan hasil belajar siswa diantaranya faktor internal siswa, faktor eksternal,". Faktor dari dalam diri (internal) meliputi kesehatan, intelegensi, minat, motivasi, dan cara belajar. Faktor dari luar diri (eksternal) meliputi orang tua, sekolah, masyarakat, dan lingkungan sekitar. Djaali (2013:99) memperjelas bahwa "faktor dari luar diri siswa yakni orang tua khususnya pendidikan orang tua, status ekonomi, rumah kediaman, presentase hubungan orang tua, dan bimbingan belajar orang tua mempunyai peranan yang sangat penting di dalam mempengaruhi pencapaian hasil belajar anak". Dari kedua pemaparan ahli tersebut dapat disimpulkan bahwa, lingkungan keluarga memiliki peranan dan tanggung jawab yang penting dalam keberhasilan belajar siswa. Lingkungan keluarga khususnya orang tua siswa merupakan lingkungan pendidikan siswa yang pertama, karena dalam keluarga pertama kali anak mendapatkan pendidikan dan bimbingan.

Arikunto (2011) menyatakan bimbingan belajar adalah pelayanan yang diberikan oleh pembimbing kepada siswa dengan tujuan untuk mengenal, memahami cara belajar secara aktif dan efisien, tertib dan disiplin belajar, baik secara mandiri maupun kelompok, serta meningkat dalam mengembangkan caracara belajar yang lebih baik. Totok Santoso (dalam Parnata,2014) menyatakan bimbingan belajar yaitu proses pertolongan dari pembimbing kepada peserta bimbing dalam memecahkan kesulitan yang berhubungan dengan masalah belajar baik di sekolah maupun diluar sekolah agar peserta bimbingan dapat menyesuaikan diri dari situasi belajarnya, dapat mengembangkan keterampilan belajarnya dan membentuk kebiasaan-kebiasaan belajar dengan sistematik dan konsisten atau ajeg dan dapat mencapai preastasi semaksimal mungkin sesuai potensi dan kemampuan yang ada pada dirinya. Sedangkan rohman (2007:198) menyatakan keluarga yaitu bapak dan ibu merupakan pusat pendidikan yang pertama dan utama yang dialami oleh anak. Sejak adanya kemanusiaan sampai sekarang ini kehidupan keluarga selalu mempengaruhi perkembangan budi pekerti setiap manusia. Pendidikan dalam keluarga muncul karena manusia memiliki naluri asli untuk memperoleh keturunan demi mempertahankan eksistensinya. Ilahi (2013:121) menyatakan, Dalam membantu proses kepribadian anak, orang tua mempunyai tanggung jawab untuk melatih kepribadian sikap, kreativitas, dan keterampilan yang menjadi motivasi keberhasilan anak. Tanggung jawab orang tua perlu diarahkan pada pemcapaian prestasi di sekolah dan mampu mengarahkan kearah masa depannya kelak. Etty (2003:61) menyatakan, Untuk mendapatkan hasil belajar yang optimal, peran dan sikap orang tua dalam mendampingi di saat anak belajar sangat di butuhkan. 
Sikap orang tua yang menunjang hal ini, misalnya: (1) membolehkan anak mengambil keputusan sendiri, (2) menghargai pendapat anak dan mendorong untuk mengungkapkannya, (3) menunjang dan mendorong kegiatan anak, (4) menikmati kebersamaan dengan anak, (5) menghargai apa yang dilakukan dan dihasilkan, (6) memberikan pujian, (7) menjalin kerjasama, (8) member waktu kepada anak untuk berpikir, merenung, dan menghayal.

Dari pemaparan ahli terkait penjelasan bimbingan belajar dan orang tua maka dapat disimpulkan bahwa bimbingan belajar orang tua adalah proses pemberian bantuan dari orang tua kepada anak yang diberikan sehari-hari dan melekat dengan kebersamaan kehidupannya berupa aspek-aspek kasih sayang, perhatian, penerimaan, tanggung jawab, dan pemberian bantuan/pertolongan untuk memecahkan kesulitan atau hambatan belajar agar dapat mencapai hasil belajar seoptimal mungkinsesuai potensi yang dimilikinya. Tujuan bimbingan secara umum adalah membantu anak agar mendapat penyesuaian yang baik di dalam situasi belajar, sehingga setiap anak dapat belajar dengan efektif dan efisien sesuai dengan kemampuan yang dimilikinya dan mencapai perkembangan yang optimal. Tujuan bimbingan dapat dibedakan menjadi dua yaitu tujuan sementara dan tujuan akhir. Tujuan sementara adalah supaya anak bersikap dan bertindak sendiri dalam situasi hidupnya yang sekarang.

Melalui bimbingan belajar yang diberikan orang tua kepada anaknya yang dilakukan secara terusmenerus secara tidak langsung akan tumbuh konsep diri yang baik pada anak itu sendiri. Djaali (2013:129) menyatakan konsep diri adalah pandangan seseorang tentang dirinya yang menyangkut apa yang ia ketahui dan rasakan tentang prilakunya, isi pikiran dan perasaanya, serta bagaimana perilakunya tersebut berpengaruh terhadap orang lain. Senada dengan pernyataan Djaali, Sobur (dalam Murti, 2010) menjelaskan konsep diri adalah pandangan pribadi yang dimiliki seseorang tentang diri sendiri atau persepsi terhadap aspek diri yang meliputi aspek fisik, aspek sosial dan aspek psikologis yang didasarkan pada pengalaman dan interaksi terhadap orang lain. Berdasarkan pendapat para ahli yang dipaparkan terkait penjelasan konsep diri, dapat disimpulkan konsep diri adalah persepsi, pikiran, kepercayaan, dan pandangan seseorang tentang dirinya sendiri yang menyangkut apa yang ia ketahui dan rasakan tentang prilakunya, isi pikiran, perasaan, dan bagaimana perilakunya tersebut berpengaruh pada orang lain serta tumbuh dari interaksi seseorang dengan orang-orang lain yang berpengaruh dalam kehidupannya, biasanya orang tua, guru, dan teman-teman. Rina (2013) mengatakan bahwa "Bimbingan belajar merupakan suatu proses pemberian bantuan kepada siswa dalam menyelesaikan masalah-masalah belajar yang dihadapi siswa, sehingga tercapai tujuan belajar yang diinginkan.

Djaali (2013:130) menyatakan, Konsep diri seseorang terbentuk dari perasaan apakah ia diterima dan diinginkan kehadirannya oleh keluarganya. Melalui perlakuan yang berulang-ulang dan setelah menghadapi sikap-sikap tertentu dari ayah, ibu, kakak dan adik atupun orang lain dilingkup kehidupannya, maka berkembanglah konsep diri seseorang. Dalam teori Psikonalisis, proses terbentuknya maupun perkembangan konsep diri disebut proses pembentukan ego (the process of ego formation). Menurut aliran ini, ego yang yang dapat mengontrol dan mengarahkan kebutuhan primitive (dorongan libido) supaya setara dengan dorongan dari super ego serta tuntutan lingkungan.Dwija (2008) menyatakan bahwa "konsep diri adalah penilaian, pandangan, dan perasaan seseorang tentang dirinya". Supriadi (2017) menyatakan bahwa "konsep diri adalah persepsi keseluruhan yang dimiliki seseorang mengenai dirinya sendiri".

Menurut Hult (dalam Budiarnawan 2014) ada tiga indikator konsep diri dan ketiga indikator ini difokuskan dalam penelitian ini yaitu, konsep diri akademis, konsep diri sosial, dan konsep diri fisik. Sedangkan menurut William D. Brooks (dalam Rahkmat, 2012) terdapat 2 ciri-ciri konsep diri yaitu konsep diri positif dan negatif. Seseorang yang memiliki konsep diri positif akan selalu percaya diri terhadap kemampuan akademik, akan selalu terbuka terhadap lingkungan sosialnya dan percaya diri terhadap kondisi fisiknya sehingga akan memabntu siswa dalam meningkatkan motivasi dalam belajarnya, sehingga dapat memperoleh hasil belajar yang optimal. Sedangkan apabila siswa memiliki konsep diri yang negatif ia akan merasa pesimis terhadap apa yang ia miliki dan sangat berpengaruh terhadap cara belajar serta hasil belajarnya, khususnya pada hasil belajar matematika.

Pembelajaran matematika adalah proses pemberian pengalaman belajar kepada peserta didik melalui serangkaian kegiatan yang terencana sehingga peserta didik memperoleh kompetensi tentang bahan matematika yang di pelajari (Santrock dalam Handayani,2017). Secara singkat Hamzah (dalam Handayani, 2017) menyatakan bahwa "hasil belajar merupakan proses belajar". Dengan kata lain, dapat dikatakan bahwa hasil belajar adalah kemampuan yang dimiliki siswa setelah menerima pengalaman belajarnya. Hasil belajar mempunyai peranan penting dalam pembelajaran. Proses penilaian terhadap hasil belajar dapat memberikan informasi kepada guru tentang kemajuan siswa dalam upaya mencapai tujuan-tujuan belajarnya melalui kegiatan belajar. Selanjutnya dari informasi tersebut guru dapat menyususn dan membina kegiatan-kegiatan siswa lebih lanjut, baik untuk keseluruhan kelas maupun individu. Berdasarkan latar belakang masalah dan landasan teori di atas dapat dikatakan bahwa 
bimbingan belajar orang tua dan konsep diri merupakan suatu hal yang penting di dalam meningkatkan hasil belajar siswa khususnya hasil belajar pada pelajaran matematika. Dengan ini, perlu dilakukannya penelitian korelasional yang berjudul "Hubungan Bimbingan Belajar Orang Tua dan Konsep Diri dengan Hasil Belajar Matematika Siswa Kelas III Semester II Di SD Gugus XII Kecamatan Buleleng Tahun Pelajaran 2017/2018".

\section{Metode}

Berdasarkan karakteristik masalah yang di teliti, penelitian ini dapat diklasifikasikan ke dalam penelitian korelasional. Penelitian korelasional merupakan suatu pendekatan umum untuk penelitian yang berfokus pada penaksiran pada kovariasi di antara variabel yang muncul secara alami untuk mengidentifikasi hubungan produktif dengan menggunakan teknik korelasi atau teknik statistik yang lebih canggih (Emzir, 2012:37).

Populasi merupakan himpunan dari unsure-unsur yang sejenis (Koyan, 2012:30). Populasi dalam penelitian ini adalah seluruh siswa kelas III semester II di SD Gugus XII Kecamatan Buleleng tahun pelajaran 2017/2018 yang berjumlah 169 orang.

Sampel adalah sebagian dari populasi yang diambil, yang dianggap mewakili seluruh populasi dan diambil dengan menggunakan teknik tertentu menurut Agung (2011:47). Dalam penelitian ini sampel yang diambil berjumlah 114 orang diambil dengan teknik Proporsional Random Sampling. Siregar (2013:31) menyatakan, proporsional sampel merupakan jumlah sampel yang diambil dari setiap strata sebanding, sesuai dengan proporsional ukurannya.

Menurut Sugiyono (2012:60), variabel adalah segala sesuatu yang berbentuk apa saja yang ditetapkan oleh peneliti untuk dipelajari sehingga diperoleh informasi tentang hal tersebut dan ditarik kesimpulan. Dalam penelitian ini terdapat dua variabel yang diteliti yaitu variabel bebas dan variabel terikat. Variabel bebas adalah variabel yang menyebabkan atau memengaruhi, yaitu faktor-faktor yang diukur, dimanipulasi, atau dipilih oleh peneliti untuk menentukan hubungan anatara fenomena yang diobservasi atau diamati. Variabel bebas biasanya dilambangkan dengan variabel X. yang termasuk variabel bebas dalam penelitian ini adalah bimbingan belajar orang tua (X1), dan konsep diri (X2). Sedangkan variabel terikat menurut sanjaya (2015:95) variabel terikat (dependent variabel) adalah kondisi atau karakteristik yang berubah, yang muncul atau yang tidak muncul ketika peneliti mengintroduksi, mengubah, dan mengganti variabel Y sejalan dengan pendapat Sanjaya, Punaji (2015:165) menyatakan variabel terikat adalah suatu variabel respon atau hasil yang dilambangkan dengan variabel Y. Adapun yang termasuk ke dalam variabel terikat adalah hasil belajar matematika.

Data yang dikumpulkan dalam penelitian ini adalah data tentang bimbingan belajar orang tua, konsep diri dan hasil belajar matematika siswa. Dalam mengumpulkan data tersebut digunkan teknik non-tes. Teknik non-tes merupakan teknik pengumpulan data yang dirancang untuk memahami pribadi siswa yang pada umumnya bersifat kualitatif. Teknik non-tes dapat berupa observasi, wawancara, angket/kuesioner, dan pencatatan dokumen.

Angket adalah daftar pertanyaan yang di distribusikan melalui pos untuk di isi dan di kembalikan atau dapat juga dijawab di bawah pengawasan peneliti (Nasution, 2014). Sedangkan pencatatan dokumen (document anylize) menurut Muljono (2014:121) merupakan salah satu cara mencari sumber informasi yang berharga bagi peneliti untuk mengumpulkan data secara kualitatif. Untuk mendapatkan data tentang bimbingan belajar orang tua dan konsep diri digunakan angket/kuesioner. Sedangkan data hasil belajar dikumpulkan dengan cara pemeriksaan dokumen seperti nilai rapor, portofolio, dan daftar nilai guru.

Sebelum digunakan, terlebih dahulu dilakukan uji coba instrument angket, yang selanjutnya dilakukan uji validitas dan reliabilitas dari ke-25 jumlah butir kuesioner bimbingangan belajar orang tua, ke 25 jumlah soal dinyatakan valid dan reliable dengan tingkat reliabilitas sangat tinggi. Sedangkan dari ke 30 jumlah kuesioner konsep diri ke-30 soal dinyatakan valid dan reliable dengan tingkat reliabilitas sangat tinggi.

Analisis statistik yang digunkan dalam penelitian ini ada dua yaitu analisis

sstatistik deskriptif dan analisis regresi. Uji prasyarat analisis dalam penelitian ini ada tiga yaitu uji normalitas, uji linieritas, dan uji multikolinieritas setelah uji prasyarat analisis terpenuhi baru dilnjutkan ke uji hipotesis dengan analisis regresi sederhana dan analisis regresi ganda.

\section{Hasil dan Pembahasan}

Setelah analisis deskriptif dilakukan, didapatkan deskripsi data terkait bimbingan belajar orang tua, konsep diri, dan hasil belajar matematika seperti pada tabel 1. 
Tabel 1. Deskripsi Data Bimbingan Belajar Orang Tua, Konsep Diri Dan Hasil Belajar Matematika

\begin{tabular}{cccccccc}
\hline Variabel & $\mathrm{N}$ & $\begin{array}{c}\text { Rentanga } \\
\mathrm{n}\end{array}$ & Minimum & Maksimum & Mean & $\begin{array}{c}\text { Std. } \\
\text { deviation }\end{array}$ & Varian \\
\hline X1 & 114 & 29 & 95 & 124 & 110,008 & 7,420 & 55,071 \\
X2 & 114 & 53 & 90 & 143 & 117,315 & 11,806 & 139,386 \\
Y & 114 & 20 & 70 & 90 & 79,438 & 4,600 & 21,169 \\
\hline
\end{tabular}

Dari data pada tabel 1, kemudian dianalisis kedalam konversi skor bimbbingan belajar orang tua, konsep diri dan hasil belajar matematika, dari hasil analisis kualifikasi bimbingan belajar orang tua siswa yang berkategori sangat tinggi sebanyak 98 orang $(85,96 \%)$, sedangkan siswa yang berkategori tinggi sebanyak 16 orang (14,04\%). Kualifikasi konsep diri sebanyak 43 orang siswa (37,72\%) berada pada kategori sangat tinggi, sebanyak 61 orang siswa (53,51\%) berada pada kategori tinggi, dan sebanyak 10 orang $(8,77 \%)$ berada pada kategori seang. Sedangkan kualifikasi hasil belajar matematika siswa, sebanyak 20 orang siswa $(17,54 \%)$ berada pada kategori sangat baik, dan sebanyak 94 orang siswa $(82,46 \%)$ berada pada kategori baik.

Uji hipotesis dalam penelitian ini adalah uji hipotesis dengan teknik analisis regresi sederhana dengan menggunakan rumus korelasi product moment dengan berbantuan SPSS 17.0 For Windows (variabel $\mathrm{X}_{1}$ dengan $\mathrm{Y}$ dan $\mathrm{X}_{2}$ dengan $\mathrm{Y}$ ) serta analisis regresi ganda atau korelasi ganda(analisis secara bersama-sama antara variabel $\mathrm{X}_{1}, \mathrm{X}_{2}$ dengan $\mathrm{Y}$ ). dalam pengujian hipotesis perlu adanya hipotesis alternative $\left(\mathrm{H}_{\mathrm{a}}\right)$. Untuk tujuan analisis data dirumuskan hipotesis nol $\left(\mathrm{H}_{0}\right)$ karena dalam analisis statistika yang diuji adalah hipotesis nol $\left(\mathrm{H}_{0}\right)$.

Sebelum melakukan uji hipotesis terlebih dahulu harus lulus uji prasyarat analisis yang pertama adalah uji normalitas. Adapun ringkasan uji normalitas dapat dilihat pada tabel 2.

Tabel 2. Ringkasan Uji Normalitas

\begin{tabular}{ccrrr}
\hline & & Bimbingan Belajar Ortu & Konsep Diri & \multicolumn{2}{c}{$\begin{array}{c}\text { Hasil } \\
\text { Belajar }\end{array}$} \\
\hline \multirow{2}{*}{$\mathrm{N}$} & & 114 & 114 & 114 \\
\hline \multirow{2}{*}{ Normal Parameters $^{\mathrm{a}, \mathrm{b}}$} & Mean & 110,0088 & 117,3158 & 79,4386 \\
\cline { 2 - 5 } & Std. Deviation & 7,42096 & 11,80619 & 4,60095 \\
\hline Most Extreme Differences & Absolute & 0,115 & 0,055 & 0,101 \\
\cline { 2 - 5 } & Positive & 0,115 & 0,055 & 0,083 \\
\cline { 2 - 5 } & Negative & $-0,097$ & $-0,048$ & $-0,101$ \\
\hline Kolmogorov-Smirnov Z & 10,223 & 0,582 & 1,080 \\
\hline Asymp. Sig. (2-tailed) & 0,101 & 0,887 & 0,194 \\
\hline
\end{tabular}

Pada tabel 2. data skor bimbingan belajar orang tua di dapat nilai Kolmogorov Smirnov sebesar 1,223, selanjutanya data skor konsep diri di dapat nilai Kolmogorov Smirnov sebesar 0,582 dan untuk data skor hasil belajar matematika di peroleh nilai Kolmogorov Smirnov sebesar 1,080 yang mana ketiga variabel tersebut nilai kolmogorov smirnov >0,05 yang berarti data dari ketiga variabel yaitu bimbingan belajar orang tua, konsep diri dan hasil belajar matemtaika berdistribusi normal.

Tabel 3. Ringkasan Uji Linieritas $\mathrm{X}_{1}{ }^{*} \mathrm{Y}$

\begin{tabular}{|c|c|c|c|c|c|c|c|}
\hline & & & $\begin{array}{l}\text { Sum of } \\
\text { Squares }\end{array}$ & $\mathrm{df}$ & $\begin{array}{l}\text { Mean } \\
\text { Square }\end{array}$ & $\mathrm{F}$ & Sig. \\
\hline \multirow{4}{*}{$\begin{array}{l}\text { hasil belajar } \\
\text { matematika* } \\
\text { bimbingan belajar } \\
\text { ortu }\end{array}$} & \multirow{3}{*}{$\begin{array}{l}\text { Between } \\
\text { Groups }\end{array}$} & (Combined) & 530,104 & 25 & 21,204 & 1,002 & 0,474 \\
\hline & & Linearity & 322,457 & 1 & 322,457 & 15,240 & 0,000 \\
\hline & & $\begin{array}{l}\text { Deviation from } \\
\text { Linearity }\end{array}$ & 207,647 & 24 & 8,652 & 0,409 & 0,993 \\
\hline & \multicolumn{2}{|c|}{ Within Groups } & 1861,967 & 88 & 21,159 & & \\
\hline
\end{tabular}




\begin{tabular}{|c|c|c|c|c|c|c|c|}
\hline & & & $\begin{array}{l}\text { Sum of } \\
\text { Squares }\end{array}$ & $\mathrm{df}$ & $\begin{array}{l}\text { Mean } \\
\text { Square }\end{array}$ & $\mathrm{F}$ & Sig. \\
\hline \multirow{5}{*}{$\begin{array}{l}\text { hasil belajar } \\
\text { matematika * } \\
\text { bimbingan belajar } \\
\text { ortu }\end{array}$} & \multirow{3}{*}{$\begin{array}{l}\text { Between } \\
\text { Groups }\end{array}$} & (Combined) & 530,104 & 25 & 21,204 & 1,002 & 0,474 \\
\hline & & Linearity & 322,457 & 1 & 322,457 & 15,240 & 0,000 \\
\hline & & $\begin{array}{l}\text { Deviation from } \\
\text { Linearity }\end{array}$ & 207,647 & 24 & 8,652 & 0,409 & 0,993 \\
\hline & \multicolumn{2}{|c|}{ Within Groups } & 1861,967 & 88 & 21,159 & & \\
\hline & \multicolumn{2}{|l|}{ Total } & 2392,070 & 113 & & & \\
\hline
\end{tabular}

Tabel 3. Menunjukkan hasil uji linieritas anatara bimbingan belajar orang tua $\left(\mathrm{X}_{1}\right)$ dan hasil belajar (Y) diperoleh hasil Deviation From Linierity = 0,993 yang mana 0,993 > 0,05, maka dapat disimpulkan data berpola linier.

Tabel 4. Ringkasan Uji Linieritas $\mathrm{X}_{2}{ }^{*} \mathrm{Y}$

\begin{tabular}{|c|c|c|c|c|c|c|c|}
\hline & & & $\begin{array}{l}\text { Sum of } \\
\text { Squares }\end{array}$ & $\mathrm{df}$ & $\begin{array}{c}\text { Mean } \\
\text { Square }\end{array}$ & $\mathrm{F}$ & Sig. \\
\hline \multirow{5}{*}{$\begin{array}{l}\text { hasil belajar } \\
\text { matematika * } \\
\text { konsep diri }\end{array}$} & \multirow{3}{*}{$\begin{array}{l}\text { Between } \\
\text { Groups }\end{array}$} & (Combined) & 1264,689 & 43 & 29,411 & 1,826 & 0,012 \\
\hline & & Linearity & 484,764 & 1 & 484,764 & 30,099 & 0,000 \\
\hline & & $\begin{array}{l}\text { Deviation from } \\
\text { Linearity }\end{array}$ & 779,926 & 42 & 18,570 & 1,153 & 0,295 \\
\hline & \multicolumn{2}{|c|}{ Within Groups } & 1127,381 & 70 & 16.105 & & \\
\hline & \multicolumn{2}{|c|}{ Total } & 2392,070 & 113 & & & \\
\hline
\end{tabular}

Tabel 4. Hasil uji linieritas antara konsep diri $\left(\mathrm{X}_{2}\right)$ dengan hasil belajar matematika (Y) diperoleh Deviation From Linierity sebesar 0,295 yang mana 0,295> 0,05. maka dapat disimpulkan bahwa data tersebut berpola linier.

Tabel 5. Ringkasan Uji Multikolinieritas

\begin{tabular}{llrr}
\hline & & $\begin{array}{c}\text { Bimbingan Belajar } \\
\text { Ortu }\end{array}$ & Konsep Diri \\
\hline bimbingan belajar ortu & Pearson Correlation & 1 & 0,645 \\
\cline { 2 - 4 } & Sig. (2-tailed) & 114 & 0,000 \\
\cline { 2 - 4 } konsep diri & $\mathrm{N}$ & 0,645 & 114 \\
\hline & Pearson Correlation & 11 \\
\cline { 2 - 4 } & Sig. (2-tailed) & .000 & 114 \\
\cline { 2 - 4 } & $\mathrm{N}$ & 114 \\
\hline
\end{tabular}

Tabel 5. tentang uji multikolinieritas dengan berbantuan SPSS 17.0 For Windows di peroleh hasil $\mathrm{rx}_{1} \mathrm{x}_{2}$ sebesar 0,645, maka dapat disimpulkan $\mathrm{rx}_{1} \mathrm{x}_{2}=0,645<0,800$ yang berarti anatar variabel bebas tidak terjadi multikolinieritas.

Tabel 6. Ringkasan Uji Hipotesis

\begin{tabular}{|c|c|c|c|c|}
\hline Variabel & $\mathrm{r}_{\text {hitung }}$ & $r_{\text {tabel }}$ & $\begin{array}{c}\text { Koefisien } \\
\text { determinasi }\end{array}$ & Hipotesis \\
\hline
\end{tabular}




\begin{tabular}{llllll}
\hline & & & $\mathrm{H}_{\mathrm{a}}$ & $\mathrm{H}_{\mathrm{o}}$ \\
\hline $\mathrm{r}_{\mathrm{xiy}}$ & 0,367 & 0,195 & $13,5 \%$ & Diterima & Ditolak \\
\hline $\mathrm{r}_{\mathrm{x} 2 \mathrm{y}}$ & 0,450 & 0,195 & $20,3 \%$ & Diterima & Ditolak \\
\hline $\mathrm{R}_{\mathrm{x} 1 \mathrm{x} 2 \mathrm{y}}$ & 0,461 & 0,195 & $21,3 \%$ & Diterima & Ditolak \\
\hline
\end{tabular}

Setelah uji prasyarat analisis terpenuhi, selanjutnya dilakukan uji hipotesis. Pada uji hipotesis pertama antara variabel $\mathrm{X}_{1}$ yaitu bimbingan belajar orang tua dengan variabel $\mathrm{Y}$ yaitu hasil belajar matematika di peroleh nilai uji signifikansi koefisien korelasi, menggunakan $r$ product moment untuk $n=$ 114 pada taraf signifikansi 5\% adalah 0,195. Dengan demikian $r_{\text {hitung }}>r_{\text {tabel }}$ atau 0,367 $>0,195$ ini berarti nilai $r_{\text {hitung }}$ signifikan dengan sumbangan sebesar $13,5 \%$. Dengan demikia Hipotesis no $\left(\mathrm{H}_{0}\right)$ ditolak dan hipotesis alternatif $\left(\mathrm{H}_{\mathrm{a}}\right)$ yang berbunyi terdapat hubungan antara bimbingan belajar orang tua dengan hasil belajar matematika siswa kela III semester II di SD Gugus XII Kecamatan Buleleng tahun pelajaran 2017/2018 diterima.

Kemudian pengujian pada hipotesis kedua anta variabel $\mathrm{X}_{2}$ yaitu konsep diri dengan variabel $\mathrm{Y}$ hasil belajar matematika, di peroleh nilai uji signifikansi koefisien korelasi, menggunakan $r$ product moment untuk $n=114$ pada taraf signifikansi $5 \%$ adalah 0,450. Dengan demikian $r_{\text {hitung }}>r_{\text {tabel }}$ atau 0,450 > 0,195 ini berarti nilai $\mathrm{r}_{\text {hitung }}$ signifikan dengan sumbangan sebesar 20,3\%. Dengan demikia Hipotesis no $\left(\mathrm{H}_{0}\right)$ ditolak dan hipotesis alternatif $\left(\mathrm{H}_{\mathrm{a}}\right)$ yang berbunyi terdapat hubungan antara konsep diri dengan hasil belajar matematika siswa kelas III semester II di SD Gugus XII Kecamatan Buleleng tahun pelajaran 2017/2018 diterima.

Untuk uji hipotesis ketiga antara bimbingan belajar orang tua $\left(\mathrm{x}_{1}\right)$ dan konsep diri $\left(\mathrm{x}_{2}\right)$ dengan hasil belajar matematika (Y) di dproleh nilai untuk uji signifikansi koefisien korelasi menggunakan R korelasi ganda untuk untuk $\mathrm{n}=114$ pada taraf signifikansi $5 \%$ adalah 0,461. . Dengan demikian $r_{\text {hitung }}>r_{\text {tabel }}$ atau

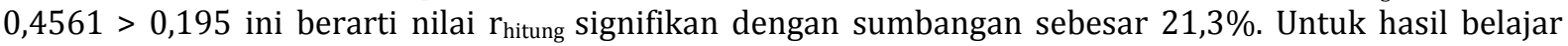

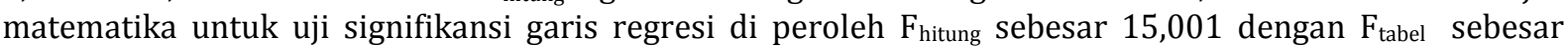
3,080 atau $F_{\text {hitung }} 15,001>F_{\text {tabel }}$ 3,080, ini berarti persamaan garis regresinya $\hat{Y}=53,761+0,082 x_{1}+$ $0,142 \mathrm{x}_{2}$ yang berarti signifikan dan dapat diberlakukan ke populasi. Dengan demikia Hipotesis no $\left(\mathrm{H}_{0}\right)$ ditolak dan hipotesis alternatif $\left(\mathrm{H}_{\mathrm{a}}\right)$ yang berbunyi terdapat hubungan antara bimbingan belajar orang tua dan konsep diri dengan hasil belajar matematika siswa kela III semester II di SD Gugus XII Kecamatan Buleleng tahun pelajaran 2017/2018 diterima.

Berdasarkan hasil analisis dan uji hipotesis maka dapat dibahas hal-hal sebagai beriktu: yang pertama hubungan antara bimbingan belajar orang tua dan konsep diri dengan hasil belajar matematika di peroleh hasil $r_{\text {hitung }}$ sebesar 0,367 yang lebih besar dari hasil $r_{\text {tabel }}$ 0,195 yang berarti hipotesis pertama signifikan, dengan sumbangan koefisien determinasi sebesar 13,5\%, maka dapat disimpulkan bahwa terdapat hubungan yang signifikan antara bimbingan belajar orang tua dengan hasil belajar matematika siswa kelas III semester II di SD Ggus XII Kecamatan Buleleng. Hasil ini di dukung oleh pendapat Ilahi (2013:121) yang menyatakan faktor yang paling mendukungkeberhasilan pendidikan anak yang paling dominan adalah peran orang tua. Hal ini sejalan dengan penelitian yang dilakukan oleh Parnata (2014)yang menyatakan bahwa terdapat hubungan yang signifikan antara bimbingan belajar orang tua dan konsep diri dengan hasil belajar matematika siswa kelas V SD Gugus V Tampaksiring.

Kedua, hubungan antara konsep diri dengan hasil belajar matematika di peroleh hasil $F_{\text {hitung }}$ sebesar 0,450 yang lebih besar dari $r_{\text {tabel }}$ 0,195 yang berarti hipotesis kedua signifikan, dengan sumbangan koefisien determinasi sebesar 20,3\%. maka dapat disimpulkan bahwa terdapat hubungan yang signifikan antara konsep diri dengan hasil belajar matematika siswa kelas III semester II di SD Ggus XII Kecamatan Buleleng. Hal ini di dukung oleh pendapat William D. Brooks (dalam Rahkmat, 2012) bahwa konsep setiap individu memiliki dua cirri konsep diri, yaitu konsep diri negatif dan positif apabila siswa memiliki konsep diri negatif maka siswa akan cenderung pesimis dan mudah menyerah dalam menghadapi permasalahannya sehingga berpengaruh terhadap hasil belajarnya, sedangkan apabila memiliki konsep diri positif maka akan seallu optimis untuk menjadi lebih baik lagi khususnya dalam meningkatkan hasil belajar. Hal ini di dukung oleh penelitian yang dilakukan Budiarnawan (2014), yang menyatakan terdapat hubungan yang positif dan signifikan antara konsep diri dan pola asuh orang tua terhadap hasil belajar IPA siswa kelas V di SD Desa Selat.

Ketiga, hubungan antara bimbingan belajar orang tua dankonsep diri dengan hasil belajar matematikadiperoleh $F_{\text {hitung }}=15,001>F_{\text {tabel }}$ 3,080 yang berarti hipotesis ke tiga signifikan dengan sumbangan koefisien detterminasi sebesar 21,3\%, maka dapat disimpulkan bahwa terdapat hubungan yang signifikan antara bimbingan belajar orang tua dan konsep diri dengan hasil belajar matematika siswa kelas III semester II di SD Ggus XII Kecamatan Buleleng. Hal ini di dukung oleh pendapat Arikunto (2011) yang menyatakan bahwa bimbingan belajar orang tua penting diberikan kepada anak untuk memahami 
kesulitan belajar anak. Sedangkan menurut Djaali tentang konsep diri (2013:130) bahwa konsep diri terbentuk melalui perasaan apakah ia diperhatikan dan diterima oleh lingkungannya. Sehingga melalui bimbingan belajar yang diberikan orang tua kepada anak secara tidak langsung akan terbentuk konsep diri khususnya konsep diri positif untuk memotivasi siswa dalam meningkatkan hasil belajar khususnya hasil belajar matematika. Hal ini di dukung oleh penelitian yang dilakukan oleh Parnata (2014)yang menyatakan bahwa terdapat hubungan yang signifikan antara bimbingan belajar orang tua dan konsep diri dengan hasil belajar matematika siswa kelas V SD Gugus V Tampaksiring.

\section{Simpulan dan Saran}

Dari hasil analisis data dan pembahasan hasil penelitian dapat disimpulkan bahwa: (1) berdasarkan hasil analisis data di peroleh rhitung sebesar 0,367 yang lebih besar dari rtabel sebesar 0,195 atau rhitung $>$ rtabel yang berarti signifikan dengan koefisien determinasi sebesar 13,5\% maka dapat disimpulkan terdapat hubungan yang signifikan anatara bimbingan belajar orang tua dengan hasil belajar matematika siswa kelas III semester II di SD Gugus XII kecamatan Buleleng tahun pelajaran 2017/2018. (2) berdasarkan hasil analisis data di peroleh rhitung sebesar 0,450 yang lebih besar dari rtabel sebesar 0,195 atau rhitung > rtabel yang berarti signifikan dengan koefisien determinasi sebesar 20,3\% maka dapat disimpulkan terdapat hubungan yang signifikan anatara konsep diri dengan hasil belajar matematika siswa kelas III semester II di SD Gugus XII kecamatan Buleleng tahun pelajaran 2017/2018. (3) berdasarkan hasil analisis data di peroleh rhitung sebesar 0,367 yang lebih besar dari rtabel sebesar 0,195 atau rhitung > rtabel yang berarti signifikan dengan koefisien determinasi sebesar $13,5 \%$ maka dapat disimpulkan terdapat hubungan yang signifikan anatara bimbingan belajar orang tua dengan hasil belajar matematika siswa kelas III semester II di SD Gugus XII kecamatan Buleleng tahun pelajaran 2017/2018. (3) berdasarkan hasil analisis data di peroleh rhitung sebesar 0,461 yang lebih besar dari rtabel sebesar 0,195 atau rhitung > rtabel yang berarti signifikan dengan koefisien determinasi sebesar $21,3 \%$ maka dapat disimpulkan terdapat hubungan yang signifikan anatara bimbingan belajar orang tua dan konsep diri dengan hasil belajar matematika siswa kelas III semester II di SD Gugus XII kecamatan Buleleng tahun pelajaran 2017/2018.

Adapun saran yang dapat disampaikan berdasarkan hasil penelitian ini adalah (1) Bagi Siswa, disarankan untuk mampu terbuka kepada orang tua terkait dengan kesulitan belajar yang dialami, agar orang tua bisa membantu untuk mengatasi kesulitan belajar. (2) Bagi Guru, disarankan untuk selalu berkejasama dengan orang tua siswa tentang kegiatan belajar dan memotivasi siswa dalam kegiatan belajar matematika. (3) Bagi Sekolah, disarankan agar selalu memperhatikan faktor-faktor lain yang dapat meningkatkan motivasi belajar serta meningkatkan hasil belajar matematika siswa. (4) Bagi Orang Tua Siswa, disarankan untuk selalu memantau perkembangan belajar anak serta selalu memberikan bimbingan belajar anak untuk memperoleh hasil belajar matematika yang optimal. (4) Bagi Peneliti Lain, disarankan untuk melakukan penelitian yang sejenis dalam lingkup yang lebih luas, dan semoga penelitian ini bermanfaat bagi pihak-pihak yang melakukan penelitian ini.

\section{Daftar Rujukan}

Agung, A. A.Gede 2016. Statistika Dasar Untuk Pendidikan. Yogyakarta: CV Budi Utama.

Anwar, Muhamad. 2015. Filsafat pendidikan. Jakarta:Prenadamedia Group.

Aprilica, Murti. 2010. Hubungan Antara Konsep Diri Dengan Perilaku Hygiene Organ Reproduksi Pada Siswa Kelas X di SMA N 1 Sambung macan Sragen. Skripsi (tidak diterbitkan). Jurnal Pendidikan Psikologi Universitas Sebelas Maret Surakarta.

Budiarnawan. 2014. Hubungan Antara Konsep Diri dan Pola Asuh Orang Tua Terhadap Hasil Belajar IPA Siswa Kelas V SD Di Desa Selat. Jurnal Mimbar PGSD Universitas Pendidikan Ganesha. Vol.2. No. 1.

Dewi, Ni Md. Novi Indrayani \& Ni Nym. Garminah, I Nym. Jampel .2013. “Kontribusi Kebiasaan Belajar Dan Konsep Diri Terhadap Prestasi Belajar Siswa Kelas IV Di Sekolah Dasar Inti Kecamatan Jembrana. Jurnal Mimbar PGSD Vol 1 No 12013 (26)

Djaali. 2013. Psikologi Pendidikan. Jakarta:Bumi Aksara. 
Dwija , I Wayan. 2008. "Hubungan Antara Konsep Diri, Motivasi Berprestasi dan Perhatian Orang Tua dengan Hasil Belajar Sosiologi pada Siswa Kelas II Sekolah Menengah Atas Unggulan di Kota Amlapura". Jurnal Pendidikan dan Pengajaran UNDIKSHA, No. 1 TH. XXXXI Januari 2008.

Emzir. 2012. Metode Penelitian Pendidikan. Jakarta: Rajawali Pers.

Eva,Siagian. 2013. Pengaruh Minat Dan Kebiasaan Belajar Siswa Terhadap Prestasi Belajar Matematika. Jurnal formatif Pendidikan Matematika Universitas Indraprasta PGRI. Vol.2. No.2.

Handayani, Dian. 2017. Pengaruh Perhatian Orang Tua dan Konsep Diri Siswa Terhadap Hasil Belajar Matematika Siswa. Jurnal Pendidikan Dasar. Vol.8. No. 1.

Ilahi, Mohamad Takdir. 2013. Ouantum Parenting: Kiat sukses Mengasuh Anak Secara Efektif dan Cerdas. Yogyakarta: Kata Hati.

Indrawati, Ni Luh Gede Eka \& Ndara T Renda. "Penerapan Model Pembelajaran Kooperatif Tipe Student Team Achievement Divisions (STAD) Untuk Meningkatkan Hasil Belajar Matematika Siswa Kelas Vi Sd No. 1 Sading Kecamatan Mengwi Kabupaten Badung Semester I Tahun Pelajaran 2016/2017 .Journal of Education Action Research Volume 1 No. 2 Agustus 2017

Indrayani , Ni Md. Novi., dkk. 2013. Kontribusi Kebiasaan Belajar dan Konsep Diri terhadap Prestasi Belajar Siswa Kelas IV di Sekolah Dasar Inti Kecamatan Jembrana. Jurnal Jurnal Ilmiah Bimbingan Konseling Vol 1 No 22013 (23).

Koyan, I Wayan. 2012. Statistik pendidikan Teknik analisis Data Kuantitatif. Singaraja: Universitas Pendidikan Ganesha

Muhsetyo, Gatot, dkk. 2009. Pembelajaran Matematika SD. Jakarta: Universitas Terbuka.

Muljono,Yaumi. 2014. Action Research (Teori, Model, dan aplikasi). Jakarta: Prenadamedia Group.

Muhhibin, S. 2015. Psikologi Belajar. Jakarta: PT RajaGrafindo Persada.

Nasution. 2014. Metode research (penelitian ilmiah). Jakarta: Bumi Aksara.

Noriasih, Ni Ketut. Pengaruh Model Pembelajaran Reciprocal Teaching Terhadap Pemahaman Bacaan Ditinjau Dari Konsep Diri Akademik Siswa Oleh Ni Ketut Noriasih. Jurnal Ilmiah Bimbingan Konseling Vol 1 No 12013 (27-45)

Parnata, I Wayan. 2014. Hubungan Bimbingan Belajar Orang Tua Dan Konsep Diri Dengan Hasil Belajar Matematika Siswa Kelas V Sd Gugus V Tampaksiring. Skripsi (tidak diterbitkan): Jurnal pendidikan dan Pengajaran Undiksha. Vol 2. No.1.

Punaji, Setyosari. 2015. Metode Penelitian Pendidikan dan Pengembangan. Jakarta: Prenadamedia Group.

Rafsanjani , Arief .2016. Menguji Konsep Diri Dibidang Akademik Sebagai Variabel Mediator Dari Pengaruh Persepsi Atas Keterlibatan Orang Tua Terhadap Hasil Belajar Ekonomi Siswa Kelas XI IPS SMA N Se Kota Malang. Jurnal Pendidikan Ekonomi Vol. 4 No. 2 Desember 2016.

Rakhmat, J. 2012. Psikologi Komunikasi. Bandung: Alfabeta.

Rina, Ni Nyoman \& Gede Sedanayasa, Ni Made Setuti.2013. "Penerapan Bimbingan Belajar Melalui Tutor Sebaya Untuk Meningkatkan Motivasi Belajar Budi Pekerti”. Jurnal Ilmiah Bimbingan Konseling Vol 1 No 12013 (46)

Siregar,Syofian. 2013. Metode Penelitian Kuantitatif. Jakarta: Kencana Predana Media Group.

Sugiyono. 2012. Metode Penelitian Pendidikan. Bandung: Alfabeta. 
Sunilawati, dkk. 2013. Pengaruh Model Pembelajaran Kooperatif Tipe STAD Terhadap Hasil Belajar Matematika Ditinjau Dari Kemampuan Numerik Siswa Kelas IV SD. Jurnal Pendidikan Dasar Pascasarjana Undiksha. Vol.3.

Supriadi, I Gede Indra \& Nyoman Dantes, Ni Ketut Suarni.2017. Efek Kausal Konsep Diri Akademik dan Minat Keguruan terhadap Ekspektasi Karier sebagai Guru dan Kaitannya dengan Sikap Profesionalisme Keguruan. Jurnal Penelitian dan Pengembangan Sains dan Humaniora Vol 1(2), h.64-72

Susanto, Ahmad. 2013. Teori Belajar dan Pembelajaran di Sekolah Dasar. Jakarta: Kencana Predana Media Group.

Suwarniti, Pt. \& I Md. Tegeh, Ni Kt. Suarni. 2013. "Pengaruh Model Pembelajaran Matematika Realistik Terhadap Hasil Belajar Pada Mata Pelajaran Matematika Kelas V SD di Gugus III Kecamatan Banjar". Vol 1 No1 2013 (68).

Undang - Undang Republik Indonesia Nomor 20 Tahun 2003 Tentang Sistem Pendidikan Nasional.

Wina, Sanjaya. 2015. Penelitian Pendidikan (Jenis, Metode, dan Prosedur). Jakarta: Prenadamedia Group. 